\title{
Exemption And Credit Methods In International Double Tax Avoidance Agreements: Literature Study
}

\author{
Prianto Budi Saptono*, \\ Ridwan Andretya Cunis, Tri Handoko Sitorus** \\ *Master of Administration Science Lecturer - Tax Management - Institute STIAMI \\ **Master of Administration Science Students - Tax Management - Institute STIAMI \\ Email:kkp.ridwan.ac@gmail.com, trihandokositorus@gmail.com
}

DOI: 10.29322/IJSRP.11.08.2021.p11603

http://dx.doi.org/10.29322/IJSRP.11.08.2021.p11603

\begin{abstract}
Double taxation is a problem that often occurs due to differences in the application of taxation principles in various countries. Corporate entities will face tax payments for multiple countries. Especially Multinational Companies which have subsidiaries in numerous countries will get a high impact. Double taxation has an impact on business activities and cash flows for the Company. Various countries gathered together to formulate a treaty on the avoidance of double taxation. This treaty is to provide flexibility for business entities in operating and increasing their economic activities. Different tax relief methods are applied in each of these agreements, both for each country and the agreement article.
\end{abstract}

Index Terms- International Double Taxation, Exemption Method, Credit Method, Tax Treaty, Double Tax Avoidance Agreement

\section{PRELIMINARY}

According to Kofler (2012), most countries generally treat a legally independent subsidiary of a domestic parent company as a separate taxable entity. This treatment led to the emergence of economic problems related to double taxation of distributions between companies across borders. The income of an exporting country of goods and services to the importing country is often included in the net of tax by the importing country. This inclusion is a significant problem in international trade. The importing country follows the simple logic that imports will contribute to the exporting country's income. Thus the income is taxed at the border of the importing country. At the same time, the exporting country also taxes the income of the Company originating from the exporting country itself. This kind of treatment raises vexing questions about taxes in both countries. Some developing countries provide tax relief to attract new industries and foreign investment. This tax relief will reduce the tax liability of the Company. The governments of these countries are included in the tax avoidance treaty group (Goenka, 1985).

According to Lokken and Kitamura (2010), income can be taxed in terms of sources and domicile based on each country's tax law in general. There are even countries that tax their citizens with a worldwide income system. Meanwhile, non-citizens are taxed based on the principle of sources obtained within the territory of the country. Suppose a citizen of one country has income from business activities or investments from another country. In that case, that citizen can be taxed on income based on domicile by his own country and based on sources by other countries.

According to Lokken and Kitamura (2010), countries generally observe international consensus on 2 (two) points:

- relief from double taxation is essential to the healthy flow of international investment and business activity

- the country of domicile of the taxpayer must bear the burden of double taxation of cross-border income of the taxpayer (according to the OECD / Organization for Economic Cooperation and Development, the cross-border investment will be hindered if there is an indication of the risk that the rate of return on the investment is taxed 2 (two) times)

Based on the consensus points above, a country can generally tax non-residents on income from sources within its country, regardless of the possibility of double taxation. But on the other hand, a country must exempt double taxation for its residents.

Tax relief methods for implementing double taxation avoidance are the primary concern of various countries in every discussion of double taxation treaties. According to Dickescheid (2014), the effect of differences in applying the double tax relief method on international taxation has long been studied in the research literature. His research compares the tax exemption method with the tax credit method in international double taxation avoidance treaties. 
One thing that is constantly debated from time to time is the choice of a tax relief method for double taxation avoidance. Of the various methods presented by experts, there are generally two methods that are most commonly used. The two widely used methods are the tax exemption method and the tax reduction method. Even in one international double taxation avoidance treaty, there can be more than one tax relief method for different income points. For this reason, the author takes this theme to observe the application of the exemption method and the reduction method in international double taxation avoidance agreements.

\section{THEORETICAL BASIS}

The doctrine of international tax law gives rise to different definitions of international double taxation. B. Spitz (1972) considers that this phenomenon occurs when two or more state tax authorities collect taxes simultaneously on the same basis. Thus, a person may bear a heavier tax liability than if he were subject to a single fiscal authority.

The definition of its origin and the mode of its manifestation is of concern to the Romanian Expert. Academician Iulian Vacarel defines international legal double taxation as "a certain taxable raw submission by two different states, for the same type of tax in the same financial year" (Ionita et al., 2003).

Professor Gheorghe D. Bistriceanu identifies this phenomenon with the following criteria: "Income and property imposed by both countries in the same type of tax and the same financial year, there is guaranteed to be double taxation." A classic example is when a non-resident is forced to pay tax on dividends in the country where the dividends were earned. And also in the country where the shareholder resides. In this case, taxation is subject to double tax for the same income, namely in the state of the source of income and the state of residence.

Experts in charge of taxation have developed OECD conventions. They commented and found that international legal double taxation arises in the following situations:

- where each state of the entrepreneur requires the total income and wealth of the same person, which means that there is total influence over the competition;

- if a resident of one country earns income or owns property in the other the contracting state and where both contracting states tax the income or property;

- Each state taxes the same person, who is not a resident of the contracting state, for the income of the contracting state or the property held there. This kind of tax is given when a non-resident has a permanent office or a permanent base through whom/who acquires or owns wealth in someone else.

The phenomenon of international legal double taxation occurs not because of differences in the structure of the taxation system but because of different concepts (criteria) that underlie the imposition of the tax. The practice fulfills two conceptions (Vacarel, 1995), namely:

- Territory design based on criteria of source, source of income, or place where profit is located;

- World or global design that is supported on the criteria of residence or nationality of the taxpayer, i.e., the registered taxpayer.

It should be noted that international double taxation can increase when both countries have the same mindset. It happens when the state implements a territorial design but makes different rules that lead to the source of income to determine the parent company's profit. International double taxation can also occur in states with varying meanings regarding the taxpayer's residence and nationality (Alexandru, 2003).

There are several methods of avoiding international double taxation, of which we only discuss two methods, namely, the tax exemption method and the tax credit method.

\section{Tax Exemption Method}

According to Gunadi (2007: 120), this method exempts any income tax received or earned abroad. It can be said that the state does not impose income tax earned by residents from outside its domicile.

This method can be divided into 2 (two) models: the full exemption model and exemption with progression model.

1. Full exemption is when all income originating from abroad earned by residents is exempted or not counted. So that only domestic income is taxed by the domicile country of origin of the resident itself, while 
2. Exemption with progression emphasizes foreign income earned by permanent residents exempted by its own country of domicile. The difference lies in the amount of income earned from abroad is calculated only to calculate taxes and apply progressive tax rates.

\section{Tax Credit Method}

According to Gunadi (2007: 124), the tax reduction method provides relief or elimination of taxes paid in the source country to be credited or deducted from foreign taxes on income taxes which are part of foreign income. This deduction can be used if income abroad is taxed both domestically and abroad. This method also aims to balance the imposition of taxes on domestic taxpayers who do not have income abroad. This tax credit method is categorized into three models: full credit method model, ordinary credit method model, and tax sparing credit method model.

\section{Full credit method;}

Taxes that have been deducted abroad can be credited in full at domicile.

Example:

Overseas income of Rp. 100,000,000 is subject to income tax of 35\% or Rp.35,000,000. While the domestic income of Rp. $200,000,000$. So that the income from domestic and foreign income is Rp. 300,000,000. If the tax is payable on Rp. 300,000,000 is Rp. 71,250,000, then the amount of tax that has been deducted abroad in the amount of Rp. 35,000,000 can be credited so that the calculation can be:

$\begin{array}{ll}\text { Tax payable } & \text { Rp71.250.000 } \\ \text { Foreign tax credit } & \text { Rp35.000.000 } \\ \text { Should be paid } & \text { Rp36.250.000 }\end{array}$

\section{Ordinary credit method}

The credit of foreign tax on national tax allocated to foreign income with the lowest limit between a.) domestic tax given to foreign income (factual tax credit), b.) tax actually owed or paid abroad on income included in global income/tax credit as a comparison between foreign income and worldwide income (theoretical tax credit).

Example:

Foreign income of Rp.100,000,000 is subject to 35\% tax, so the tax to be paid is Rp.35,000,000. Meanwhile, the domestic income of Rp. 200,000,000. Then the theoretical tax credit is obtained by:

$\frac{100.000 .000}{300.000 .000} \times \operatorname{Rp} 71.250 .000=\operatorname{Rp} 23.750,000$.

The tax credit allowed is the smallest tax credit between the theoretical tax credit and the actual tax credit, so the calculation is:

Tax payable $\quad R p 71.250 .000$

Tax credit article 24

Should be paid $\quad \boldsymbol{R p}$ 47.500.000

\section{Tax sparing credit method}

Income from the source country receiving tax exemption facilities (tax holiday) is considered to remain tax payable in the source country to avoid taxed income (country of domicile).

\section{WRITING METHOD}

The writing method we use is a literature study-based method (qualitative method). A literature study is a series of activities related to collecting library data, reading and taking notes, and managing research materials (Zed, 2008:3). In this case, the authors choose the literature study conducted by Lokken and Kitamura (2010) regarding "Credit vs. Exemption: a Comparative Study of Double Relief in the United States and Japan" and Dickescheid (2014) on "Exemption vs. Credit Method in International Double Taxation Treaties."

\section{DISCUSSION AND STUDY}




\section{Case 1}

$\mathrm{X}$ Corp is incorporated under the laws of country $\mathrm{X}$, manufactures goods in country $\mathrm{X}$, and sells goods in country $\mathrm{X}$ and other countries/regions. Sales in country $\mathrm{Y}$ are made through a subsidiary of Y Corp (X Corp holds 50\% equity) incorporated under the laws of country Y. In 2020, X Corp produced goods at the cost of 60,000 and sold them to third-party customers in country Y for 80,000 (price reasonable), and Y Corp sells to a third-party customer in country Y for 100,000. In addition to the cost of goods, X Corp. has 4,000 operating costs, and Y Corp. has 6,000 costs. Y Corp pays 4,200 income taxes in country Y (30\% of 14,000 net income) and distributes 4,900 dividends to X Corp. Country Y provides for a $20 \%$ withholding tax on dividends. Therefore, when distributing dividend, $\mathrm{X}$ Corp receives a net after-tax of 3,920 (980 dividend tax).

If country $\mathrm{X}$ is Indonesia, then the income tax is calculated as follows:

\begin{tabular}{|l|r|}
\hline Revenue & 80,000 \\
\hline Cost of goods sold & $(60,000)$ \\
\hline Gross profit & 20,000 \\
\hline Operational expense & $(4,000)$ \\
\hline Operational profit & 16,000 \\
\hline Dividend income & 4,900 \\
\hline Profit before tax & 20,900 \\
\hline
\end{tabular}

The tax payable is $4,598(20,900 \times 22 \%)$. If the tax credit method complies with Indonesia's regulations, we would first compare the full credit method and the limited tax credit method.

The full credit method value of dividend tax is 980 .

The value of the limited tax deduction credit method on dividends is

\begin{tabular}{|c|c|c|c|c|c|}
\hline 4,900 & & \multirow{2}{*}{\multicolumn{3}{|c|}{4,598}} & \multirow{2}{*}{1,078} \\
\hline 20,900 & & & & & \\
\hline
\end{tabular}

In accordance with the maximum tax credit limit, the value of 980 withholding taxes on overseas dividends is still lower than that. Therefore, the tax credit allowed under Indonesian rules is 980.

The remaining tax paid to the Indonesian government is 3,618 (4,598-980).

Suppose Indonesia and country $\mathrm{Y}$ has an agreement to avoid double taxation and state that dividend transactions are exempt from withholding taxes (taxes are imposed in their respective countries using the exemption method). In that case, country Y does not collect income tax, and 4,598 is paid to the Indonesian government. However, if the exemption is from Indonesia not to tax dividends taxed in country $\mathrm{Y}$, Indonesia will lose the potential tax on dividend income of $98(1,078-980)$.

\section{Case 2}

$\mathrm{X}$ Corp is incorporated under the laws of country $\mathrm{X}$, produces goods in country $\mathrm{X}$, and sells goods in country $\mathrm{X}$ and other countries. Sales in country Y are made via a subsidiary of Y Corp (X Corp holds 50\% shareholding) established under the laws of country Y. In 2020, X Corp produced goods at the cost of 60,000 and sold them to Y Corp for 80,000 (fair price). ) and Y Corp. sells to third-party customers in country $\mathrm{Y}$ for 100,000. In addition to the cost of goods, X Corp. has 4,000 operating expenses, and Y Corp. has 6,000 costs. Y Corp pays 4,200 income taxes in country Y (30\% of 14,000 net income) and distributes 4,900 dividends to X Corp. Country Y provides for a $25 \%$ withholding tax on dividends. So that when distributing dividends, X Corp received a net after-tax of 3,675 (dividend tax 1,225).

If country $\mathrm{X}$ is Indonesia, then the following income tax calculation applies: 


\begin{tabular}{|l|c|}
\hline Revenue & 80,000 \\
\hline Cost of goods sold & $(60,000)$ \\
\hline Gross profit & 20,000 \\
\hline Operational expense & $(4,000)$ \\
\hline Operational profit & 16,000 \\
\hline Dividend income & 4,900 \\
\hline Profit before tax & 20,900 \\
\hline
\end{tabular}

The amount of tax payable is 4,598 (20,900 x $22 \%)$. Using the tax deduction method according to Indonesia's rules, we will first compare the full credit method and the limited tax deduction credit method.

The full credit method value of dividend tax is 1,225 .

The value of the limited tax deduction credit method on dividends is

\begin{tabular}{|r|l|l|l|l|}
\hline 4,900 & X & 4,598 & $=$ & 1,078 \\
\hline 20,900 & & &
\end{tabular}

Based on calculating the maximum tax credit limit, the value of dividend tax withheld abroad of 1,225 is already above the maximum threshold. Therefore the tax credit that is allowed according to the rules in Indonesia is 1,078.

The remaining tax to be paid to the Indonesian government will be 3,520 (4,598-1078).

Suppose Indonesia and country $\mathrm{Y}$ has a double taxation avoidance agreement and state that dividend transactions are exempt from withholding tax (taxable in their respective countries using the tax exemption method). In that case, country Y does not collect income tax at all, and 4,598 is paid to the government of Indonesia. However, suppose the exemption is from Indonesia not to tax dividends that have been taxed in country Y. In that case, Indonesia will not experience a loss because the portion of income tax on dividends of Rp 1,078 is credited with all taxes withheld by country Y.

\section{Discussion of Case 1 and Case 2}

- The two cases above are the same, except for case 1 , country Y (source) imposes a dividend tax of $20 \%$, and in case 2 , country $\mathrm{Y}$ (source) imposes a dividend tax withholding of $25 \%$.

- In the first case, the amount of tax 980 withheld by country Y can be credited in full from the tax owed in Indonesia. Therefore, $\mathrm{X}$ Corp will enjoy tax justice from both countries, and its tax obligations will not be doubled.

- In the second case, the value of the tax withheld by country Y of 1,225 cannot be credited at all because the maximum threshold of proportional taxable income on the dividend itself is 1,078. So X Corp lost 147 because it could not be credited against the tax payable in Indonesia. The higher withholding tax rate $(25 \%)$ on dividends in country Y compared to the tax rate in Indonesia $(22 \%)$ creates an uncredited tax difference.

- If country Y does not apply a dividend rate cut (exempt dividend withholding using the exemption method), the dividend will be taxed in its entirety in Indonesia. So that country $\mathrm{Y}$ itself loses its right to tax the dividends, while country $\mathrm{Y}$ has the right to tax dividends originating from its territory according to the source principle.

- On the other hand, if country $X$ does not tax the dividend income using the exemption method because it has been taxed by country $\mathrm{Y}$, country $\mathrm{X}$ will lose the tax potential. Meanwhile, based on the territorial principle, country $\mathrm{X}$ has the right to tax the dividends received by $\mathrm{X}$ Corp, domiciled in its territory.

- To mediate this effect, the two countries agreed not to apply the exemption method on passive income (such as dividends, interest, and royalties) in the double taxation avoidance agreement. This action is for the sake of justice for the source country and the country of domicile. The two countries will agree to apply the credit method. The tax rate on passive income is determined reasonably for both countries and allows companies to credit their taxes fully.

\section{E. CONCLUSION}

Based on the discussion of existing case examples, both the exemption method and the tax credit method as the tax relief method have their own positive and negative sides. This positive and negative effect will affect taxes in the source country and the domicile country. The tax exemption method seems simpler since only a domicile country has the right to tax, but this is unfavorable for the source country. Source Country also has the right to tax (primarily passive income) since the passive income activity is in the source country. The middle way to provide justice to both parties involved is to apply the tax reduction method for the taxing source country. The country of domicile can also tax, but it allows companies to credit taxes withheld in the source country. 


\section{REFERENCES}

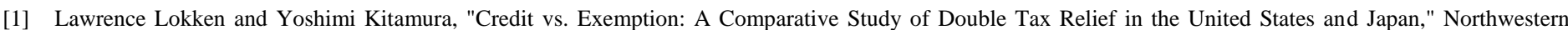
Journal of International Law \& Business, Vol 30, Summer 2010

[2] B.B. Goenka, "Relief Through Double Tax Avoidance Agreements," Foreign Trade Review Double Tax Avoidance Agreements, 1985

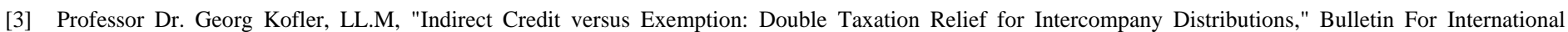
Taxation, February 2012

[4] Nicoleta Barbuta-Misu, Florin Tudor, "The International Double Taxation-Avoiding Methods," June 2009

[5] Murti Ayu Hapsari, "Penyelesaian Permasalahan Pajak Berganda Internasional”, Desember 2019

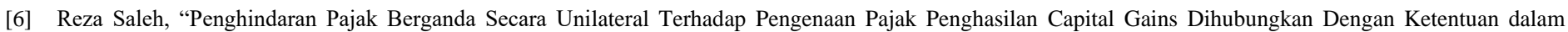
Perjanjian Penghindaran Pajak Berganda Secara Bilateral”, Jurnal Ekonomi dan Bisnis, Vol 1, Juli 2012

[7] Thomas Dickescheid, "Exemption vs. Credit Method in International Double Taxation Treaties," International Tax and Public Finance, November 2004

[8] Gunadi, 2007, Pajak Internasional, Lembaga Penerbit Fakultas Ekonomi Universitas Indonesia, Jakarta

[9] Drs. Chairil Anwar Pohan, M.Si., MBA, 2018, Pedoman Lengkap Pajak Internasional Konsep Strategi dan Penerapan, Jakarta

[10] http://wina0103.blogspot.com/2017/11/bab-6-metode-penghindaran-pajak.html

\section{AUTHORS}

First Author - Prianto Budi Saptono, Master of Administration Science Lecturer - Tax Management - Institute STIAMI, prianto.budi@gmail.com.

Second Author - Ridwan Andretya Cunis, Master of Administration Science Student - Tax Management - Institute STIAMI, kkp.ridwan.ac@gmail.com

Third Author - Tri Handoko Sitorus, Master of Administration Science Student - Tax Management - Institute STIAMI, trihandokositorus@gmail.com

Correspondence Author - Ridwan Andretya Cunis \& Tri Handoko Sitorus, kkp.ridwan.ac@gmail.com, trihandokositorus@gmail.com, +6285668081368 or +6281269082191. 